\title{
A Research on Quality Work Life of Women Working in it (Information Technology) Sectors Around Chennai Metropolitan Region
}

\author{
E.Hemapriya, S. Ramachandran
}

\begin{abstract}
Indian financial system noticed a flood beginning the managerial territory to paintings after the opening of the economy within the most current decade of the 20 th century. With robotization and computerization of commercial enterprise circumstances proliferate open entryway became opened to women advised mostly in IT and programming territories wherein pay is energizing and motion for most sorts of running elements in normal regions. Be that as it is able to, this goes with an extended jobs recurring work and time stress cutoff is empowering work surroundings. along family unit responsibilities equality working lifestyles emerge as being a troublesome problem for ladies IT authorities. on this paper the expert trying to discover a work-existence lady equality trouble IT government from the metropolis of Chennai. The examination was pushed among 50 girl IT experts thru the research of the survey and problems, for example, long stretches of work, own family commitments and expert advancement is considered as a parameter esteem existence the working paper likewise endeavors to discover a cause in the back of adjustment of operating lifestyles and to check the size of the mending
\end{abstract}

Keywords:: high-quality of work life, operating life soundness, work stress, own family commitments.

\section{INTRODUCTION}

motion. Privatization and globalization of the Indian government's methodology has gotten expansive changes inside the Indian financial system closing 25 years. the interest put it on the market has seen the enterprise grow open entryways for younger proficient body of workers. It has modified the real profile of a delegate institution away with great remuneration and worldwide creation. every other concept of a few double calling ascending from it. As this trademark losing often expanding wide variety of ladies who wandered into occupations which can be usually visible as a manufacturer of home. The girl presently has transformed into a reasonable little bit of workplace. there was an adjustment in the factor of view of human beings are dealt with as a provider as home carers or children delivery to ladies each as suppliers and suitable to cope with the hobby of the nuclear own family additionally. Be that as it may, people who wind up getting an up-and-comer, controlled callings, disregarding the numerous pieces of existence out of doors of work, as an instance, the character of energy speculation with the teenager and own family, pastime time and time for top class cases. that is going to excessive paintings pressure, working hours stretchable and goalbased totally sporting activities.

Revised Manuscript Received on September 14, 2019.

E.Hemapriya, Research Scholar, Department of MBA, Bharath Institute of Higher Education and Research, Chennai, Tamilnadu, India.

Dr.S. Ramachandran, Director, MM Institute of Management, MMDU University, Ambala, Haryana, India. (E-mail: prakashvenkee07@gmail.com)

adjustments in social structure rising from severa professional couple (or single discern households) precipitated the possibility of distributing the agency, for instance, childcare and care of the improvement of trustees. there's an apparent want to regulate and arrange the family's desires and the requirements of the calling. In a changing society like India, in which the customary paintings of girls as homemakers and guardians profoundly settled in, crafted with the aid of the family a check equality for women. working women is a business in itself and proceeded to name for viable budgetary self-rule, he wishes to likewise hold him create kids to reach at their folks. both of these profoundly cited and do fee to 1 without ignoring the alternative is an extraordinary challenge.

at some point of the maximum recent decade maximum Indian culture has seen a flood in light of a valid problem for girls within the body of workers, especially within the IT business is an instantaneous decrease of globalization and produce a extremely good deal of possibilities for ladies educated. considering the extending wide variety of women in the IT enterprise, there's a need to break down the character of working lifestyles and the miracles of the Indian girl's night out IT succesful interior and out increasingly conspicuous.

\section{REVIEW LITERATURE}

best work existence thought has been grabbing centrality for the research because of the truth that it's far one of the industrial organisation related issues affecting talent of shops in an association in addition as in performing paintings related to family. With creating reputation of personnel for handling the breaking aspect and the interface between their art work and non-work lives, the path of movement for realistic art work life sporting occasions had been a demand for numerous dating within the company global.

1. Igbaria, Magid and Guimaraes Tor (1993) investigated the "Antecedents and outcomes of task pleasure amongst facts middle personnel". The determinants and aftereffects of career pleasure for facts middle (IC) paintings energy are getting no concept, paying little heed to their centrality to the feasible use and use of laptop improvement in affiliations. on this exam, the makers studies the precursors and consequences of profession pride for IC outlets. five sections of profession pleasure, particularly, paintings, supervision, teammates, pay, and headway, were 


\section{A RESEARCH ON QUALITY WORK LIFE OF WOMEN WORKING IN IT (INFORMATION TECHNOLOGY) SECTORS AROUND CHENNAI METROPOLITAN REGION}

investigated other than at the whole organisation delight.

2. Oldham at el., (1996)of their paintings on "Delegate Creativity: private and Contextual factors at work" reviewed the possibility and joint responsibilities of outlets' imagination - suitable singular characteristics and three traits of the definitive setting - work capriciousness, strong supervision, and controlling supervision - to a few suggestions of worker's' creative execution: patent exposures made, duties to an affiliation idea software program, and supervisory tests of inventiveness. A entire of 171 dealers (118 from office A; fifty three from place of job B) agreed to participate inside the assessment. This variety mirrors a response pace of 87 percentage of those at the begin came to in administrative center An and of seventy five percent of these in workplace $\mathrm{B}$, a general help pace of 83 percent. 37 percent of the individuals had been women. The suggest age become 41 years, and the imply definitive residency degree turned into 12.seventy five years. The particular steering level changed into "enterprise university or particular college degree." Interviews with HR chiefs exhibited that the measurement and paintings profiles of the respondents were ordinary of the overall open inside the sharing paintings unit.

3. Syed S. Andale et al, (2004) pondered the " Participation in the place of business: Gender views from Bangladesh". in this exploration paintings, the creators stated, cooperation in authoritative fundamental management close to developing nations are restricted, especially from a sex factor of view. In slight of a assessment of government and personal division representatives in Dhaka, Bangladesh, this exam investigated the degree to which ladies had been blanketed inside the frame of people and the manner the two sexual orientations see their cooperation in simple control. The hierarchical surroundings is seen as sound, even as correspondence most of the sexual orientations does no longer reflect full-size obstacles or hostilities.

four. Desh Raj (2009) decided the "Nature of labor existence in BHEL". An example length of 40 people protecting numerous stages of association structure and numerous workplaces. round 30 polls have been conveyed many of the human beings within the manufacturing line premises. 10 surveys for the legitimate diploma. It manages six variables, specially, work culture, nature of work life, ceaseless analyzing, creativeness, corporation stability and loose running. the writer broke down the gathered data through utilizing the recurrence and rate approach. The outcome shows that the representatives are fulfilled and mollified at the equal time as running for BHEL under the modern-day conditions

5. Neeraj Kaushik et.Al (2014) displayed the "equity in the paintings surroundings: A have a look at of Gender issues in Indian businesses". In developing worldwide locations like India, changing financial and social conditions required running of girls 50 regardless of their faith, elegance, or societal function. $\mathrm{Be}$ that as it may, simultaneously, it raised various associated troubles like managing the family, working circumstance, and so on. in this examination, the creators meant to contemplate number one problems like intercourse generalization, sex segregation, and lewd behavior almost about the Indian circumstance.

The above scrutinizes have given fantastic detail of cost art work lifestyles circumstance in IT component in a summarized way. anyways uncommon composing is available on paintings lifestyles leveling of women IT delegates of Chennai. Chennai being a colossal land spread has its intrinsic trouble of residence, using and vital price of residing. Thusly the existing assessment is an task made with the aid of the investigator to take a gander on the art work and circle of relatives life of women IT specialists ${ }^{\text {ec }}$ scary profession at their administrative center nearby their own family responsibility.

\section{Target Of Examine}

(i) To look at the work and circle of relatives related factors that effect the paintings-own family parity of girls IT specialists ofChennai.

(ii) To apprehend the problems they face and the kind of adapting device they use to perform artwork circle of relatives balance.

\section{Technique}

The evaluation have become done on the crucial recognition that, submit headway, ladies want to take in IT as a calling as a result of its inborn noticed little bit of leeway of profitable pay and all inclusive advent. Regardless, with converting situation this will preserve helpful for substantially sorted out institutions. large part of IT occupations are time sure, have an different work manner of existence and executives are all of the all the greater mentioning. wary popularity can exhibit that diverse lively female IT professionals becoming a member of at junior degree do now not make it to pinnacle whilst stood out from their male accomplices. A massive a part of the time the woman offers excessive centrality to her promise to circle of relatives and teenagers thru changing off her grasp improvement. For coordinating this examination critical statistics emerge as assembled from 50 female IT experts of assumed IT institutions organized in and round Chennai Metropolitan area. The statistics was accrued to understand their strolling hours, using time, family responsibilities and the demanding situations to fulfill goals for mate and youngsters. The information became destitute down the usage of essential bifurcation and the use of weighted everyday. A close and notable examination changed into completed to locate the critical reason pressure of problems and its repercussion on artwork existence stability. The demography of respondents are in step with the accompanying. 


\begin{tabular}{|l|l|}
\hline Type of Respondents & No. of Respondents \\
\hline Mamied & 35 \\
\hline Unmarned & 13 \\
\hline Divorcee & 02 \\
\hline Women having kids & 16 \\
\hline Women not having kid & 15 \\
\hline Average Age & 38 \\
\hline Graduate & 18 \\
\hline Post Graduate & 32 \\
\hline Junior Executives & 19 \\
\hline Middle level executives & 22 \\
\hline Senior level executives & 09 \\
\hline Average Income(INR) Not CTC & 1.2 Lakh p.a \\
\hline
\end{tabular}

\section{Observations}

\section{Working days/working hours/commutingtime}

In this investigation it was discovered that the IT organizations working in the five-day plan. Generally endorsed working hours are 9 hours out of every day. Yet, as a general rule in normal IT officials working 11 hours of the day. This happens on the grounds that now and again, to fulfill the time constraint complete official task must stretch past the planned working hours is typical. Additional data uncovered that one of the methods for driving takes around 2 hours for IT officials .But higher the standard deviation demonstrated a high variety driving time from 0.5 hours to 4 hours greatest. The base is watched relies upon the separation among working environment and living arrangement.

Consequently it tends to be finished up from these perceptions that ladies working in the IT segment in Chennai is relied upon to spend at least 12 hours out of each day for the situation identifying with the expert life in ordinary working conditions. This influences the typical family life, causing both physical and mental weakness which lead to pressure.

\section{(2) FamilyLiability}

The data on the business visionary's point of view on family issues have been broke down in this area incorporate the general managers' observations and necessities of the family. Rating for various viewpoints (both positive and negative) are appeared in Table 1 and Table 2 separately under.

\begin{tabular}{|c|c|c|c|}
\hline \multirow{2}{*}{\multicolumn{2}{|c|}{ Policy }} & Level of Agreement & \\
\hline & & $\begin{array}{l}\text { Mean Score (At the rating of } \\
4 \text { ) }\end{array}$ & Standard Deviation \\
\hline \multicolumn{2}{|c|}{$\begin{array}{l}\text { Managementaccommodativetofamily } \\
\text { needs }\end{array}$} & \begin{tabular}{l|l}
2.8 \\
\end{tabular} & 0.91 \\
\hline \multicolumn{2}{|c|}{$\begin{array}{l}\text { Family members encouraged to join } \\
\text { company } \\
\text { celebrations }\end{array}$} & 2.5 & 0.57 \\
\hline \multicolumn{4}{|c|}{$\begin{array}{l}\text { Table.2 Rating of Respondents on Family and Work (Non Positive } \\
\text { Aspects) }\end{array}$} \\
\hline \multirow[t]{2}{*}{ Policy } & \multicolumn{3}{|c|}{ Level of Agreement } \\
\hline & \multicolumn{2}{|c|}{ MeanScore (At the rating of 4 ) } & Standard Deviation \\
\hline $\begin{array}{l}\text { Keeping work ahead of family } \\
\text { is } \\
\text { appreciated }\end{array}$ & \multicolumn{2}{|c|}{2.7} & 0.53 \\
\hline $\begin{array}{l}\text { Discouragement of } \\
\text { leave for } \\
\text { family issues }\end{array}$ & \multicolumn{2}{|l|}{2.5} & 0.83 \\
\hline Family takes a back seat & \multicolumn{2}{|l|}{2.07} & 0.92 \\
\hline
\end{tabular}

The studies exposed that control is accommodative to circle of relatives wishes to a degree of $67 \%$ score and furthermore loved ones are advised to sign up for organization festivities (rating of sixty 5\%).but simultaneously the exam indicated that management acknowledges whether the representatives keep paintings in front of own family (appraising of sixty five\%).The management demoralizes to income go away on guise of circle of relatives problems (score of fifty five\%) and family takes a secondary living room on organizations thing of view (rating of 52\%). Henceforth but in modern-day the rating of troubles on fantastic angles are extra whilst contrasted with critiques on terrible viewpoints, yet the groups are an increasing number of concerned about their income and make a few in truth looking own family pushed movement like causing a circle of relatives to get collectively. in any case, issues like disappearing for own family necessity are notencouraged.

Published By:

Blue Eyes Intelligence Engineering 


\section{A RESEARCH ON QUALITY WORK LIFE OF WOMEN WORKING IN IT (INFORMATION TECHNOLOGY) SECTORS AROUND CHENNAI METROPOLITAN REGION}

\section{(2)Child Care and Domestic Commitment}

ladies people in Indian scenario are limited to take wreck for youngster care and home Commitment so also the case for women IT professional sin Chennai.Though joining back to job is permitted, however it is continuously went with riders in an IT corporation.50\% of respondents stated that the bundle deal on go back could be a whole lot less whilst contrasted with one's partner who has no longer enjoyed the reprieve. As there may be fast exchange in innovation the modified specialized situation throughout the damage also can make it contradictory for the representative at the same time as rejoining as communicated by way of manner of nineteen $\%$ respondents. $31 \%$ of respondents felt that on go back after a wreck one wishes to comply with the available opportunity both as far as rank and innovation degree

\section{(3)Personal Life and Career Figure}

in spite of the reality that there takes place to be a few contention in maintaining up gifted greatness due to residential duty; $17 \%$ of respondents communicated of relinquishing individual existence for gifted greatness. A dominant element sixty seven\% experience the equal sporadically however now not in a popular way. Out of those sixty seven\% a lion's percentage (i.E sixty two\%) were single young girls and some different (i.E 38\%) having a solid family bolster like they had been for the maximum element ultimate with their folks or in legal suggestions. In a similar vein half of of respondents stated that from time to time they couldn't perform at work environment in an agreeable way due to their circle of relatives responsibility. For around $33 \%$ of respondents it is an regular surprise. Be that as it could, $17 \%$ respondents were each expert or fortunate sufficient for not encountering this form of circumstance. As a trendy situation there may be actual a few issue of good deal whilst adjusting (as a substitute coordinating) individual and professional lifestyles. Taking a gander at reactions we're in a position to deduce that $67 \%$ of respondents concur that there had been settles on professional and character life. $16 \%$ respondents stated it became clashing. no person however $17 \%$ ought to make a compelling reconciliation of each.

\section{ANALYSIS \& RESULTS}

As positioned thru the examiner the variety of going for walks hour isn't uniform if there have to emerge an event of women IT specialists in Chennai metropolis. The working hours evaluation as in line with nature of journey doled out to them. At any price there is no noteworthy collection in setting extensive kind of hours at artwork spot as indicated by the age, enlightening capacity and enjoy of the ladies expert basically. At any fee younger married ladies laborer of mid-Nineteen Thirties or past due Nineteen Twenties having teenager are gradually pushed on the same time as interfacing their art work and non-paintings lives. teen care and administering nuclear circle of relatives obligations were regarded due to the fact the maximum pressing enthusiasm for them on the own family. nearby manner of this they may be having their life companion running in 9 to 6 timetable thusly via and big depending upon housemaids and a number of them placed their children in crèches. Any disrupting impact in this contraption activates warfare and infection. maximum of the respondents (eighty five\%) are encountering life-style diseases like strain, mental scene, high blood stress and lack of sexual yearning for horrifying scouring among assistants. It has furthermore been obviously located from modern examination that on the way to receive twofold occupation as it should be, girls IT experts in Chennai are beginning at now watched, in changing off both at own family or on the hold close existence.

\section{CONCLUSION}

at the off chance that there ought to emerge an occasion of a girl capable in IT sector it's miles simple to understand the ground truth and find a few type of settlement amongst master and character life for reaching succesful enormity. with out this the ladies succesful in IT region could preserve being accrued at the lower level and could not have the alternative to upward thrust to the more distinct elegance of the motion dynamic framework via using matching their male accomplices.

it's miles cutting-edge want that enterprise must be sensible enough in the direction of ladies expert in IT aspect whilst completing artwork versatility plans specifically in a city like Chennai which has its inborn boundaries of massive fee of residing, first-rate processes from artwork spot to residence and lion's offer being nuclear circle of relatives occupant with each the existence associate being calling pushed, work life adjustment is a largest check. in addition, amazingly youngsters are being the extremely good causality. they're being prevented from securing parental concept continuously. It includes pressure for each chief, girls laborer, their friends and first rate circle of relatives individuals to make a legitimate ordinary society by way of the usage of consolidating paintings and family existence. family that is the essential middle rate of Indian manner of life want to not to persevere thru further as ladies having similar potential outcomes need to furthermore be no longer disappointed or crippled to recognize their employment goal. beside the point artwork existence equality may also have a low excellent life-style horrifying family difficulty and unsatisfactory execution on the artwork places (or a bad impact on satisfactory yield on the paintings place).

\section{REFERENCES}

1. Castells, Manuel (2000) The ascent of system society, Oxford,Blackwell

2. own family friendly working Hours Taskforce (2009), bendy working: strolling for households, operating for enterprise, a file with the aid of the family pleasant running Hours Taskforce,Pp.19.

3. Giddens, Anthony. 1990. The final results of Modernity Stanford: Stanford college Press.

4. Igbaria, Magid and Guimaraes Tor (1993) "Precursors and effects of profession success amongst statistics attention representatives". Diary of control records structures". Spring ninety 3.Vol. nine, Iss: four, pp. one hundred forty five - 174 .

5. Oldham, Greg R; Cummings, Anne (1996) "consultant innovativeness: individual and logical variables at 
paintings", Academy of control, Vol. 39, No. 3, pp. 607634.

6. Syed S. Andaleeb, Gretchen Vanneman Wolford (2004) "investment inside the work environment: intercourse points of view from Bangladesh", women In control review, Vol. 19, Iss: 1, pp. fifty two - sixty 4

7. AggreyNzomoKavalu (2009) "Ann assessment of firstrate of labor life in a university" en.Articlesgratuits.Com.

8. Neeraj Kaushik, Anita Sharma, Veerander Kumar Kaushik (2014) "Uniformity inside the place of job: A have a look at of Gender troubles in Indian agencies", magazine of management development, Vol. 33, Iss: 2, pp. ninety-106 